\title{
PAINTINGS ANALYZED
}

PLATE PAGE

XXIV. The Sainte Victoire from Bellevue . . . . . . . . . . . . . Ior

XXV. The Sainte Victoire at Early Morning . . . . . . . . . . ${ }_{102}$ [Supplementary illustration: Portrait of Kahnweiler, by Picasso, p. 103]

XXVI. The Sainte Victoire from Les Lauves . . . . . . . . . . . . 104

XXVII. L'Estaque . . . . . . . . . . . . . . . . . . . . . 106

XXVIII. View of L'Estaque. . . . . . . . . . . . . . . . . . 107

XXIX. Provençal Mas near Gardanne . . . . . . . . . . . . . . ro8

XXX. Le Pont des Trois Sautets . . . . . . . . . . . . . . . . 112

XXXI. Trees and Rocks at Bibemus . . . . . . . . . . . . . . . II3

XXXII. The Quarry at Bibemus . . . . . . . . . . . . . . . . II4

XXXIII. In the Forest of the Château Noir . . . . . . . . . . . . II6

XXXIV. Rocks in the Forest of the Château Noir . . . . . . . . . . . Ir 8

XXXV. The Mill near the Pont des Trois Sautets . . . . . . . . . . . I2 I

XXXVI. View of Gardanne . . . . . . . . . . . . . . . . . . 122

XXXVII. The Sainte Victoire from Bellevue . . . . . . . . . . . . . I24

XXXVIII. The Sainte Victoire from Beaureceuil . . . . . . . . . . . . 127

XXXIX. Landscape . . . . . . . . . . . . . . . . . . . . ${ }_{\mathrm{I} 28}$ 
